Biogeosciences Discuss., doi:10.5194/bg-2016-297, 2016

Manuscript under review for journal Biogeosciences

Published: 24 August 2016

(c) Author(s) 2016. CC-BY 3.0 License.

\title{
Rooting and plant density strongly determine greenhouse gas budget of water hyacinth (Eichhornia crassipes) mats
}

Ernandes Sobreira Oliveira Junior ${ }^{1 *}$; Yingying Tang ${ }^{1 *}$; Sanne J.P. van den Berg²; Leon P. M. Lamers ${ }^{1,3}$;

5 Sarian Kosten ${ }^{1}$

${ }^{1}$ Department of Aquatic Ecology and Environmental Biology, Institute for Water and Wetland Research,

Radboud University Nijmegen, P.O. Box 9010, 6500 GL Nijmegen, The Netherlands

${ }^{2}$ B-WARE Research Centre, P.O. Box 6558, 6503 GB, Nijmegen, The Netherlands.

${ }^{3}$ Department of Aquatic Ecology and Water Quality Management, Wageningen University and Research

Centre, P.O. Box 47, 6700 AA Wageningen, The Netherlands

${ }^{*}$ Corresponding author:

Ernandes Sobreira Oliveira Junior

Dept. of Aquatic Ecology \& Environmental Biology

Radboud University Nijmegen,

Heyendaalseweg 135, 6525 AJ Nijmegen, The Netherlands

Email: e.sobreira@science.ru.nl

*These authors equally contributed to the paper.

Running head: Rooting and plant density strongly determine greenhouse gas budget of water hyacinth. 
Biogeosciences Discuss., doi:10.5194/bg-2016-297, 2016

Manuscript under review for journal Biogeosciences

Published: 24 August 2016

(c) Author(s) 2016. CC-BY 3.0 License.

Keywords: Greenhouse gases, invasive species, experimental ecology, nutrient cycling, population

\section{Abstract}

Water hyacinth occurs in numerous tropical and subtropical countries, either as a native or as an invasive exotic species, where it can establish large and dense mats. The plant is also frequently used for water purification and bioremediation purposes. Although it is a free-floating species, the plant roots into the sediment of shallow waters, tapping into the sediment nutrient pool. Its long and extensive root system strongly increases nutrient absorption, resulting in high growth rates and concurring high carbon sequestration rates. On the other hand, the plants may also fuel methane $\left(\mathrm{CH}_{4}\right)$ production as dense mats may deplete oxygen in the surface water and sediment below, which in combination with the high production of organic matter creates favorable conditions for methanogenesis. We hypothesize that water hyacinth vegetation acts as a strong greenhouse gas (GHG) sink due to its high growth rates, especially when (sediment) nutrient availability is high. Still, this sink may be counterbalanced by $\mathrm{CH}_{4}$ release, which will be most pronounced when the plants are rooting in the sediment due to potential $\mathrm{CH}_{4}$ shuttling from the sediment through the roots and leaves into the atmosphere (chimney effect). To mechanistically unravel the influence of water hyacinth on nutrient dynamics and greenhouse gas fluxes, we performed an aquarium experiment in which plant density and root access to the sediment were manipulated. Although plant cover led to lower concentrations of dissolved total phosphorus (DTP) and phosphate, there were no effects of density or rooting. We found no vegetation effect on the ebullition of $\mathrm{CH}_{4}$, but its diffusion was 4.5 times higher at high plant coverage. Rooting increased $\mathrm{CH}_{4}$ diffusion by 1.3 (high density) and 4 times (low density), demonstrating the chimney effect that we hypothesized. Independent of rooting, however, water hyacinth at high density sequestrated less carbon compared to low density, possibly due to space limited growth 
Biogeosciences Discuss., doi:10.5194/bg-2016-297, 2016

Manuscript under review for journal Biogeosciences

Published: 24 August 2016

(c) Author(s) 2016. CC-BY 3.0 License.

and self-shading. Overall, water hyacinth enhanced $\mathrm{CH}_{4}$ emissions, especially when rooted. Due to water hyacinth's high $\mathrm{CO}_{2}$ sequestration rates, the overall $\mathrm{GHG}$ budget in terms of $\mathrm{CO}_{2}$ equivalents still resulted in water hyacinth mats being near-neutral or even a GHG sink, depending on water hyacinth density. Our results show that the effect of water hyacinth mats on GHG fluxes strongly depends on both plant density and contact with the sediment. This indicates that, when making regional GHG balances, not only plant presence but also its density and water depth - regulating sediment-root contact - should be taken into account.

Key words: floating plant, nutrient dynamic, $\mathrm{CH}_{4}$ emission, carbon dioxide sequestration, greenhouse warming potential.

\section{Introduction}

Water hyacinth (Eichhornia crassipes) is notorious worldwide because of the problems it poses to economy, society and ecology when occurring at high densities (Villamagna and Murphy, 2010; Malik et al., 2007). Its high tolerance range for environmental conditions including $\mathrm{pH}$, temperature and nutrients (Gutierrez et al., 2001; Wilson, Holst and Rees, 2005) provides an ample spectrum of colonization, and explains its wide-spread occurrence around the world. Its fast growth rates and rapid dispersal through asexual reproduction explains its ability to form large floating mats comprising high biomass (Pinto-Coelho and Greco, 1999).

The search for useful end products for this large amount of biomass has resulted in its appliance as a source for bioenergy production (Chanakya et al., 1993), fodder (Jianqing et al., 2001), bio-fertilizer (Zhao et al., 2012), and paper fiber (Reddy and Tucker, 1983). Water hyacinth is also frequently used for water purification and bioremediation purposes because of its high nutrient uptake rates (Aoyama and Nishizaki, 1993; Mandi, 1994; Polprasert and Khatiwada, 1998). Nutrient availability strongly determines Eicchornia's growth rate as well as 
Biogeosciences Discuss., doi:10.5194/bg-2016-297, 2016

Manuscript under review for journal Biogeosciences

Published: 24 August 2016

(c) Author(s) 2016. CC-BY 3.0 License.

nutrient allocation (Xie et al., 2004). Maximum nutrient uptake efficiency is typically reached in the early growth stage (Reddy, Agami \& Tucker, 1989; Reddy, Agami \& Tucker, 1990), explaining the formation of big mats in a few days (Tellez et al., 2008).

Water hyacinth's high growth rate results in high carbon dioxide $\left(\mathrm{CO}_{2}\right)$ uptake at rates of $3.4-5.4 \mathrm{~g} \mathrm{C}-\mathrm{CO}_{2}$ $5 \mathrm{~m}^{-2}$ day $^{-1}$ as reported for tropical lakes (Peixoto et al., 2016). In these lakes, the vegetation even sets off open water $\mathrm{CO}_{2}$ emissions, turning the system into $\mathrm{CO}_{2}$ sink. While water hyacinth growth will decrease $\mathrm{CO}_{2}$ emissions, its presence may simultaneously increase the emission of methane $\left(\mathrm{CH}_{4}\right)$ (Banik, Sen, and Sen, 1993), having a global warming potential (GWP) of 34 times $\mathrm{CO}_{2}$ over a 100 year time scale (Myhre, Shindell and Bréon, 2013). Therefore, even relatively low rates of $\mathrm{CH}_{4}$ emissions could offset the high $\mathrm{CO}_{2}$ assimilation, turning water hyacinth mats into a greenhouse gas (GHG) source. The high density of water hyacinth suppresses light penetration and therefore photosynthetic activity in the water below. In combination with reduced $\mathrm{O}_{2}$ diffusion from the atmosphere into the water by its cover, this can result in anaerobic conditions below the plant mat (Reddy and DeBusk, 1991). Research performed in ditches and tanks showed that the combination of decreasing $\mathrm{O}_{2}$ concentrations and high organic matter production by water hyacinth favors $\mathrm{CH}_{4}$ emission. This effect was strongest after multiple years, probably due to organic matter accumulation (Banik et al., 1993).

Aquatic plants rooting in the sediment tend to enhance $\mathrm{CH}_{4}$ emissions by transporting $\mathrm{CH}_{4}$ directly from the sediment to the atmosphere (Bastviken, 2009), a process referred to as the chimney effect. Although water hyacinth is generally reported as a floating plant, the plant can root in the sediment when the water level is sufficiently low (less than $50 \mathrm{~cm}$; personal observation), potentially increasing $\mathrm{CH}_{4}$ emissions. This enlarged GHG effect may, however, be counterbalanced by enhanced growth rates and therefore $\mathrm{CO}_{2}$ uptake rates, due to increased nutrient uptake from both sediment and water. 
Biogeosciences Discuss., doi:10.5194/bg-2016-297, 2016

Manuscript under review for journal Biogeosciences

Published: 24 August 2016

(c) Author(s) 2016. CC-BY 3.0 License.

All in all, the effects of water hyacinth mats on GHG emissions are therefore not at all straightforward. Only few studies have investigated the effects of water hyacinth on total GHG emissions $\left(\mathrm{CH}_{4}\right.$ and $\left.\mathrm{CO}_{2}\right)($ Banik et al., 1993; Peixoto et al., 2016; Attermeyer et al., 2016), and none have included the effects of plant density or rooting. Moreover, the few studies that investigated the effect of water hyacinth on GHG balance showed 5 contrasting results (Banik et al., 1993; enhanced $\mathrm{CH}_{4}$ emissions; and Attermeyer, et al., 2016; decreased $\mathrm{CH}_{4}$ emissions). We hypothesize that the differences found may be due to variation in density and whether or not the plants are rooted in the sediment. We therefore used a full-factorial, controlled indoor aquarium experiment aiming to elucidate the effects of plant density and sediment rooting on the nutrient dynamics and GHG fluxes of water hyacinth vegetation.

\section{Materials and methods}

\subsection{Experimental set-up}

The experiment was conducted in 24 glass aquaria of $24 \mathrm{~L}(20 \times 20 \times 60 \mathrm{~cm} ; \mathrm{I} \times \mathrm{w} \times \mathrm{h})$ filled with a layer of $7 \mathrm{~cm}$ of fresh sediment, and a layer of $38 \mathrm{~cm}$ of demineralized water. The sediment was collected from a eutrophic drainage ditch (Ede, The Netherlands; $51^{\circ} 59^{\prime} 43.58^{\prime \prime} \mathrm{N}, 5^{\circ} 38^{\prime} 38.91^{\prime \prime} \mathrm{L}$ ) in September 2014, and was sieved with a $5.0 \mathrm{~mm}$ sieve to remove stones and vegetation remnants. Sediment characteristics were determined at the beginning of the experiment (Table 1). The aquaria were placed in a water bath at $23^{\circ} \mathrm{C}$ in the greenhouse facilities of the Radboud University (Nijmegen, The Netherlands). A light frame of $220 \mu \mathrm{mol} \mathrm{m}^{-2} \mathrm{~s}^{-1}$ PAR (16h light/8h dark) was provided by Philips Green Power 400V/1000 WE lamps in a New E-Papillon 1000 W armature, to provide sufficient light in case of cloudy conditions. 
Biogeosciences Discuss., doi:10.5194/bg-2016-297, 2016

Manuscript under review for journal Biogeosciences

Published: 24 August 2016

(c) Author(s) 2016. CC-BY 3.0 License.

Water hyacinth was collected from a commercial breeder (Nijmegen, the Netherlands) and cultivated in the greenhouse for approximately 10 months prior to the experiment, on organic sediment to which slow-release phosphorus granules. The experiment lasted for 59 days, from October to December 2014. The aquaria were randomly assigned to controls without plants, low density (50\% of water hyacinth coverage) or high density (100\% coverage) ( $n=8$ for each treatment). In half of the treatments, a mesh (1.0 mm mesh size) was placed just above the sediment $(n=12)$ to prevent the plants from rooting in the sediment, dividing the plant treatments into rooted and non-rooted treatments. There were 4 controls without, and 4 with a mesh (jointly referred to as 'controls'). We added individual water hyacinths to each aquarium: 1) $160 \mathrm{~g}$ to the low density treatment with mesh (nonrooted $-50 \% n R$ ) or without mesh (rooted $-50 \% R$ ); and 2) $413 \pm 2.63$ g to the high density treatment with mesh (non-rooted -100\%nR) or without mesh (rooted-100\%R) (Fig. 1). To maintain the low coverage, water hyacinth was harvested partially at day 31 and 45 .

\subsection{Chemical analyses}

Dissolved oxygen (DO), $\mathrm{pH}$ and temperature were measured weekly at both the surface and bottom of the water column, using a portable multi-meter ( $\mathrm{HQ} 40 \mathrm{~d}$ multi, $\mathrm{HACH}$, Loveland, Colorado, U.S.A.). Surface and porewater samples were collected anaerobically every week during the experiment using ceramic soil moisture samplers (SMS rhizons, Eijkelkamp, Giesbeek, Netherlands). Total inorganic carbon (TIC) of water samples was measured with an Infra-red Gas Analyzer (IRGA; ABB Analytical, Frankfurt, Germany). Concentrations of $\mathrm{PO}_{4}{ }^{3-}$, $\mathrm{NO}_{3}{ }^{-}$and $\mathrm{NH}_{4}{ }^{+}$in the water samples were measured colorimetrically on an Auto-Analyzer 3 system (Bran \& 
Biogeosciences Discuss., doi:10.5194/bg-2016-297, 2016

Manuscript under review for journal Biogeosciences

Published: 24 August 2016

(c) Author(s) 2016. CC-BY 3.0 License.

of dissolved total P (DTP) were measured by inductively coupled plasma-optical emission spectrometry (ICP-OES; IRIS Intrepid II, Thermo Fisher Scientific, Franklin, MA, U.S.A.). Dissolved organic carbon (DOC) in water samples was measured with a TOC-L CPH/CPN analyzer (Shimadzu, Kyoto, Japan) at the end of the experiment.

Sediment samples were collected at the start and end of the experiment, and subsequently dried for $48 \mathrm{~h}$

5 at $60^{\circ} \mathrm{C}$. Dry samples were heated for 4 hours at $550^{\circ} \mathrm{C}$ and re-weighed to determine organic matter content. Dried sediment (200 mg) was digested in a microwave oven (MLS-1200 Mega, Milestone Inc., Sorisole, Italy) using $4 \mathrm{ml} 65 \% \mathrm{HNO}_{3}$ and $1 \mathrm{ml} \mathrm{30 \%} \mathrm{H}_{2} \mathrm{O}_{2}$ to determine total sediment $\mathrm{Fe}, \mathrm{Al}$, $\mathrm{Ca}$ and $\mathrm{P}$ concentrations. Digested solutions were analyzed by ICP-OES (see above). Olsen P extracts (plant available P) was determined by extraction according to Olsen (1954), whereas a $\mathrm{NaCl}$-extraction (exchangeable $\mathrm{NH}_{4}{ }^{+}$and $\mathrm{NO}_{3}{ }^{-}$) was performed as described by Tomassen et al., (2004).

\subsection{Greenhouse gas flux measurements}

\subsubsection{Diffusive flux}

After 30, 38 and 45 days greenhouse gas $\left(\mathrm{CO}_{2}\right.$ and $\left.\mathrm{CH}_{4}\right)$ diffusive fluxes were measured during the day Greenhouse Gas Analyzer (Picarro Inc., Santa Clara, CA, USA). The lid was sealed air-tight with paste (Terostat IX, Teroson $\mathrm{GmbH}$, Heidelberg, Germany).

\subsubsection{Ebullitive flux}

Total $\mathrm{CH}_{4}$ fluxes (ebullitive + diffusive) were measured 3 times (on day 31, 39 and 46) during a period of 24 hours. During this time the glass lid (equipped with a rubber septum) was closed as described before. The increase in $\mathrm{CH}_{4}$ concentration during 24 hours was determined by sampling the headspace (in duplicate) through 
Biogeosciences Discuss., doi:10.5194/bg-2016-297, 2016

Manuscript under review for journal Biogeosciences

Published: 24 August 2016

(c) Author(s) 2016. CC-BY 3.0 License.

the septum at the start and the end of the incubation and subsequent analyses on a gas chromatograph (HP 5890 equipped with a Porapak Q column (80/100 mesh), a flame ionization detector (GC-FID, Hewlett Packard, USA) and oven temperature $120^{\circ} \mathrm{C}$ ). The total amount of $\mathrm{CH}_{4}$ emitted was calculated by multiplying the change in $\mathrm{CH}_{4}$ concentration in the headspace between $t=0$ and at the end with the volume of the headspace. The ebullitive

5 fluxes were calculated by subtracting diffusive $\mathrm{CH}_{4}$ fluxes determined the day before from the total amount of $\mathrm{CH}_{4}$ emitted.

\subsubsection{Global Warming Potential}

To evaluate the net GHG effect we used a global warming potentials (GWPs) of 34 for $\mathrm{CH}_{4}$ converting to $\mathrm{CO}_{2}$-eq fluxes as described by Myhre et al. (2013).

10

\subsection{Plant measurements}

At the start of the experiment four extra plants were dried $(148.37 \pm 13.18 \mathrm{~g} \mathrm{FW}$ and $9.00 \pm 0.94 \mathrm{~g} \mathrm{DW})$ and used to analyze initial nutrient contents. At the end of the experiment all plants were collected. Water hyacinths were divided into leaves, petioles, and roots. The fresh plant samples were weighed and dried for $48 \mathrm{~h}$ at $60^{\circ} \mathrm{C}$, after which they were weighed again, grinded and homogenized. Subsequently, $200 \mathrm{mg}$ of dry plant material was grinded and digested to determine total $\mathrm{P}$ concentrations in plants as described for the chemical analysis of sediment. An additional $3 \mathrm{mg}$ of dry plant samples was combusted to determine $\mathrm{C}$ and $\mathrm{N}$ content with an elemental analyzer (Carlo Erba NA 1500, Thermo Fisher Scientific, Waltham, MA, USA).

\subsection{Plant measurements}


Biogeosciences Discuss., doi:10.5194/bg-2016-297, 2016

Manuscript under review for journal Biogeosciences

Published: 24 August 2016

(c) Author(s) 2016. CC-BY 3.0 License.

(c) (i)

Shapiro-Wilk's test and Bartlett's test were conducted to test normality of residuals and equality of error variances, respectively. Non-normal or heteroscedastic data were log transformed to meet these two requisites. Linear mixed models were used to test the main effects and interactions of treatments on water characteristics, DO, GHG fluxes, GWPs and the ratios of $C: N, C: P$, and N:P in different plant tissues with the aquarium number as a random effect, by using $\mathrm{R}$ package $\mathrm{nlme}$. Tukey tests were performed to find differences between treatments by using R package multcomp. The effects of treatments and differences between treatments were considered significant if $P<0.05$. All statistical analyses were carried out using the software program $\mathrm{R}$ (version $3.2 .1 ; \mathrm{R}$ development Core Team, 2015). All graphs were plotted by using SigmaPlot (v.11 Systat Software Inc, 2008).

10

\section{Results}

\subsection{Biogeochemistry in water column and sediment}

Dissolved oxygen (DO) concentrations did not vary in time ( $P>0.05$ for all treatments; data not shown), and were below saturation value $\left(8.3 \mathrm{mg} \mathrm{L}^{-1}\right.$ at $\left.22{ }^{\circ} \mathrm{C}\right)$. Average $\mathrm{DO}$ concentrations in the water layer were significantly lower in aquaria with plants $\left(3.5 \pm 0.2 \mathrm{mg} \mathrm{L}^{-1}\right)$ compared to the control aquaria without plants $(5.7 \pm$ $0.4 \mathrm{mg} \mathrm{L}^{-1}, \mathrm{X}^{2}=9.20, P<0.05$ ), without a density effect (Fig 2).

The treatments including water hyacinth had about 10-50\% lower concentrations of DTP and phosphate $\left(\mathrm{PO}_{4}{ }^{3-}\right)$ in the surface water compared to the controls $\left(\mathrm{X}^{2}=79.82, P<0.001\right.$ and $\mathrm{X}^{2}=84.03, P<0.001$ for DTP and $\mathrm{PO}_{4}{ }^{3-}$ respectively; Table 2$)$. In addition, they had lower $\mathrm{NO}_{3}{ }^{-}$concentrations in the surface water $\left(X^{2}=69.38, P<\right.$ 
Biogeosciences Discuss., doi:10.5194/bg-2016-297, 2016

Manuscript under review for journal Biogeosciences

Published: 24 August 2016

(c) Author(s) 2016. CC-BY 3.0 License.

\subsection{Nutrient concentrations in different plant tissues}

Plant coverage or rooting did not show effects on nutrient concentrations in different plant tissues $(P>0.05)$. For low density, $\mathrm{P}$ concentrations in petioles were higher in rooted plants than in not-rooted plants $(P<0.01 ; \mathrm{Fig}$ S1A). In addition, only low-density treatments showed higher $\mathrm{P}$ concentrations in petioles at the end of the experiment compared to the start $(P<0.01$; Fig S1A). For all treatments $P$ concentrations in roots were significantly higher at the end of the experiment than at the start of the experiment $(P<0.001$; Fig S1B). Furthermore, only the high density rooted plants had higher $\mathrm{N}$ concentrations in petioles at the end of the experiment compared to the start $(P<0.001 ; \mathrm{Fig} \mathrm{S} 2)$. $\mathrm{N}$ concentrations in petioles were higher in the treatment with high density rooted plants than all other treatments $(P<0.001$; Fig S2). 0.85) $\left(X^{2}=38.75, P<0.001\right)$, and the N: $P$ ratio in the roots was lower at the end than at the start $\left(X^{2}=24.44, P<\right.$ 0.001).

\subsection{Greenhouse gas fluxes}

Total $\mathrm{CH}_{4}$ fluxes were highest at high density (ANOVA for density effect; $X^{2}=8.72, P<0.05$ ). This was mostly due to the high diffusion rates. At low density, diffusive $\mathrm{CH}_{4}$ emissions were significantly higher in aquaria with rooted water hyacinth $\left(X^{2}=9.59, P<0.01\right)$ (Fig. $\left.4 A\right)$. At high coverage the rooted water hyacinth tended to have higher diffusive $\mathrm{CH}_{4}$ fluxes as well, albeit non-significant $(P=0.90)$. On average, $\mathrm{CH}_{4}$ ebullition was $33.1 \pm 28.7 \mathrm{mg}$ 
Biogeosciences Discuss., doi:10.5194/bg-2016-297, 2016

Manuscript under review for journal Biogeosciences

Published: 24 August 2016

(c) Author(s) 2016. CC-BY 3.0 License.

water hyacinth functioned as a source, whereas the treatments with water hyacinth functioned as a $\mathrm{CO}_{2}$ sink $\left(\mathrm{X}^{2}=17.08, P<0.001\right)$ (Fig $\left.4 \mathrm{~B}\right)$.

\section{Discussion}

We found that water hyacinth presence significantly increased diffusive $\mathrm{CH}_{4}$ fluxes. These fluxes increased with plant density and, especially when plants were rooting in the sediment (Fig. 4A), stressing the role of water depth. Due to water hyacinth's high $\mathrm{CO}_{2}$ sequestration rates, the overall GHG budget in terms of $\mathrm{CO}_{2}$ equivalents still resulted in water hyacinth mats being near-neutral or even a GHG sink, depending on water hyacinth density (Fig. 5).

\subsection{The effect of water hyacinth on oxygen and $\mathrm{CH}_{4}$ emissions}

Water hyacinth's cover lead to lower oxygen concentrations in the water column (Fig. 2). Low oxygen concentrations below other floating plant species have been reported in field and lab studies (Masifwa, Twongo and Denny, 2001; Nahlik and Mitsch, 2006) and have been attributed to the suppression of $\mathrm{O}_{2}$ diffusion across the air-water interface, decrease of primary production in the water column due to lower light availability and the high oxygen demand of decomposing plant material (Reddy and DeBusk, 1991).

Low oxygen concentrations may, however, result in increased $\mathrm{CH}_{4}$ emissions (Bastviken et al., 2008) which may, at least partially, explain why the diffusive $\mathrm{CH}_{4}$ emission was up to 17 times higher in aquaria with water hyacinth compared to the controls. Water hyacinth has previously been reported as a $\mathrm{CH}_{4}$ enhancer ( 2 to 5 times more $\mathrm{CH}_{4}$ emissions from water hyacinth mats compared to open waters) (Banik et al., 2013). Other studies, in 
Biogeosciences Discuss., doi:10.5194/bg-2016-297, 2016

Manuscript under review for journal Biogeosciences

Published: 24 August 2016

(c) Author(s) 2016. CC-BY 3.0 License.

contrast, showed 2.6 times higher $\mathrm{CH}_{4}$ fluxes from open waters compared to from water hyacinth mats (Attermeyer et al., 2016). We postulate that this discrepancy may well be driven by different underlying mechanisms. For one, the densities might have differed, with higher densities leading to higher methanogenic rates. Additionally, along the roots of water hyacinth, $\mathrm{CH}_{4}$ oxidation takes place due to the metanotrophic activity

5 (Yoshida, et al., 2014), and due to a radial oxygen loss provided by this plant (Kosten, et al., submited). Variation in root biomass and exudate loss, the composition and activity of microbial communities, and water and sediment composition can be expected to affect $\mathrm{CH}_{4}$ oxidation rates and hence $\mathrm{CH}_{4}$ emission rates. In our study, we found that rooting led to 1.3 and 4 times higher diffusive $\mathrm{CH}_{4}$ emissions at high and low plant density, respectively, most possibly caused by the direct transportation of the $\mathrm{CH}_{4}$ produced in the sediment to the atmosphere through the aerenchyma of roots and leaves, thereby escaping $\mathrm{CH}_{4}$ oxidation (Bastviken, 2008; Thomas, et al., 1995).

Higher coverage led to higher diffusive $\mathrm{CH}_{4}$ fluxes, presumably due to the production of (dissolved) organic matter substance and further lowering of $\mathrm{O}_{2}$ concentrations. If the chimney effect indeed occurs, rooting in the sediment might avoid the formation of bubbles in the sediment, thereby decreasing ebullition and enhancing the proportion of $\mathrm{CH}_{4}$ emitted by the plant tissue. We did, however, not find a significant effect of rooting on ebullition in our study.

\subsection{The effect of water hyacinth on nutrient dynamics and carbon dioxide emissions}

The percentage coverage by plants and their access to the sediment did not change nutrient uptake and allocation in a consistent way, although the high density rooting plants showed higher N: P ratios (Fig. 3), due to higher N concentration (Fig S2). Relatively high N concentrations under high-density conditions have been found in the field as well and have been related to $\mathrm{N}$ supply to the plant (Reddy et al., 1989). The general absence of a 
Biogeosciences Discuss., doi:10.5194/bg-2016-297, 2016

Manuscript under review for journal Biogeosciences

Published: 24 August 2016

(c) Author(s) 2016. CC-BY 3.0 License.

strong effect of root access to the sediment on plant nutrient contents suggests that the plants are capable of mobilizing nutrients from the sediment even without direct contact. This has also been demonstrated for the floating macrophyte Stratiotes aloides, for which the lowering of $\mathrm{O}_{2}$ levels due to high coverage can promote $\mathrm{P}$ release from the sediment by weakening the bonds of Fe-P complexes (Harpenslager, et al., 2016). The fact that water column nutrient concentrations tented to be higher in the treatments where the plants are rooted in the sediment (Table 2) suggests, however, that the plants preferably tap into the rich sediment nutrient pools directly. Porewater concentrations of $\mathrm{N}$ and $\mathrm{P}$ were 220 and 30 times higher than in the surface water (results not shown). Egeria densa, Hydrilla verticillata, and Myriophyllum spicatum have been reported to only take up P from the sediment (Barko and Smart, 1980). concomitant $\mathrm{CO}_{2}$ sequestration. We did not find, however, higher $\mathrm{CO}_{2}$ sequestration in our rooted treatments. We only found a clear difference between the densities, with on average 1.6 times lower $\mathrm{CO}_{2}$ sequestration rates at high densities, which we attribute to the limited space for growth.

On average our plant treatments sequestrated $-3.4 \pm 2.2 \mathrm{~g} \mathrm{CO}_{2} \mathrm{~m}^{-2}$ day $^{-1}$, regardless of density and the position of the roots. This is notably higher than sequestration rates of other aquatic plants, such as Typha domingensis and Eichhornia azurea, showing sequestration rates around $-0.09 \mathrm{~g} \mathrm{CO}_{2} \mathrm{~m}^{-2}$ day $^{-1}$ (Gripp et al., 2013). The rates we measured are in the range between -3.4 and -5.4 $\mathrm{g} \mathrm{CO}_{2} \mathrm{~m}^{-2}$ day ${ }^{-1}$, found for E.c. in field conditions (Peixoto et al., 2016; Attermeyer et al., 2016).

In aquaria without water hyacinth, $\mathrm{CO}_{2}$ fluxes took place leading a $24 \mathrm{~h}$ net emission of, on average, $0.3 \mathrm{~g} \mathrm{CO}_{2}$ $\mathrm{m}^{-2}$ day $^{-1}$ (Fig. 4). The net emissions from the non-vegetated controls contrast the net $\mathrm{CO}_{2}$ sequestration in the plant treatments indicating that the plants offset the $\mathrm{CO}_{2}$ emissions from open waters. 
Biogeosciences Discuss., doi:10.5194/bg-2016-297, 2016

Manuscript under review for journal Biogeosciences

Published: 24 August 2016

(c) Author(s) 2016. CC-BY 3.0 License.

\subsection{Effects of water hyacinth on the overall GHG balance}

Under the experimental conditions of our study in the absence of water hyacinth, $\mathrm{CH}_{4}$ emissions were modest and net $\mathrm{CO}_{2}$ emissions took place, leading to an overall emission of GHG (Fig. 5). At low density, however, water hyacinth was a net sink of GHGs, regardless of the position of the roots. At high density $\mathrm{CO}_{2}$ sequestration only partially counterbalanced $\mathrm{CH}_{4}$ emissions, thereby making the system become a small GHG source.

We here show that whether water hyacinth is a GHG sink or source depends on the balance of its effect on $\mathrm{CH}_{4}$ emissions and $\mathrm{CO}_{2}$ uptake rates. This balance, in turn, depends on density and whether or not they are rooting in the sediment with partially contradicting effects when it comes to $\mathrm{CO}_{2}$ and $\mathrm{CH}_{4}$. The plants tended to enhance $\mathrm{CH}_{4}$ emissions especially at high density and when rooting in the sediment, whereas their $\mathrm{CO}_{2}$ uptake rates were highest at low density where the growth was not space limited and nutrient availability per plant was higher.

Ebullition played an important role in the overall GHG balance, since it accounted, on average, for $58 \%$ of the total $\mathrm{CH}_{4}$ emissions for all treatments and even reached $62 \%$ at low density. Underlining once more that ebullition is one of the most important forms of $\mathrm{CH}_{4}$ contribution to the atmosphere (Coulthard, et al., 2009). rates are enhanced and hence can trigger a regional effect offsetting the greenhouse gas emissions for open waters. Using water hyacinth for nutrient-rich wastewater purification under a relatively low density (like $50 \%$ coverage) by regular harvest will likely reduce the emission of $\mathrm{CH}_{4}$ and increase the sequestration of $\mathrm{CO}_{2}$, especially when roots are prevented from reaching the sediment. As a main conclusion, we here showed that access to the sediment, as related to water depth, and plant density are crucial factors influencing both nutrient 
Biogeosciences Discuss., doi:10.5194/bg-2016-297, 2016

Manuscript under review for journal Biogeosciences

Published: 24 August 2016

(c) Author(s) 2016. CC-BY 3.0 License.

dynamics and GHG emissions, which may explain the discrepancies reported in literature and should be taken into account when making regional GHG balances.

\section{Author contribution}

5 The experiment was designed by Ernandes S. Oliveira Junior, Yingying Tang, Sarian Kosten and Leon P. M. Lamers, and executed by Ernandes S. Oliveira Junior, Yingying Tang and Sanne van den Berg. The manuscript was written by Ernandes S. Oliveira Junior and Yingying Tang with contribution of all co-authors.

\section{Acknowledgements}

The authors would like to thank Walter Hendrickx, Yvette Evers for the Water hyacinth maintenance and Gerard van der Weerden for providing experimental space in the greenhouse facilities. We thank Paul van der Ven, Ankie De Vries-Brock, Germa Verheggen, Sebastian Krosse, and Roy Peters for their assistance with the chemical analyses. Han Wang was essential for the experiment implementation and data acquisition. Ernandes Sobreira was funded by the Coordenação de Aperfeiçoamento de Pessoal de Nível Superior - CAPES by the Science without Borders scholarship program Process BEX 13607/13-8, and the project was funded by Koninklijke Nederlandse Akademie van Wetenschappen (KNAW) and Fundação de Amparo a Pesquisa de Mato Grosso (FAPEMAT). Yingying Tang was funded by the China Scholarship Council (CSC; file number 201206140019). Sarian Kosten was supported by NWO-VENI grant 86312012.

\section{References}


Biogeosciences Discuss., doi:10.5194/bg-2016-297, 2016

Manuscript under review for journal Biogeosciences

Published: 24 August 2016

(c) Author(s) 2016. CC-BY 3.0 License.

(c) (i)

Aoyama I. \& Nishizaki H. (1993) Uptake of nitrogen and phosphate, and water purification by water hyacinth Eichhornia crassipes (Mart.) Solms. Water Science and Technology 28(7), 47-53.

Attermeyer K., Flury S., Jayakumar R., Fiener P., Steger K., Arya V., Wilken F., van Geldern R. \& Premke K. (2016) Invasive floating macrophytes reduce greenhouse gas emissions from a small tropical lake. Scientific reports 6 .

Banik A., Sen M. \& Sen, S. (1993) Methane emissions from waterhyacinth-infested freshwater ecosystems. Chemosphere 27(8), 1539-1552.

Barko J. \& Smart R. (1980) Mobilization of sediment phosphorus by submersed freshwater macrophytes. Freshwater Biology. 10, 3 (1980), 229-238.

Bastviken D., Cole J. J., Pace M. L. \& Van de Bogert M. C. (2008) Fates of methane from different lake habitats: Connecting whole-lake budgets and methane emissions. Journal of Geophysical Research: Biogeosciences $113(\mathrm{G} 2)$.

Bastviken D. (2009) Methane, p. 783-805. InG. E. Likens [ed.],Encyclopedia of inland waters. Elsevier. Chanakya H., Borgaonkar S., Meena G. \& Jagadish K. (1993) Solid-phase biogas production with garbage or water hyacinth. Bioresource technology 46(3), 227-231.

Coulthard T. J., Baird A. J., Ramirez J. \& Waddington M. (2009). Methane dynamics in peat: importance of shallow peats and a novel reduced-complexity approach for modeling ebullition. In: Baird AJ, Belyea LR, Comas X, Reeve AS, Slater LD (eds) Carbon cycling in northern peatlands, geophysical monograph series 184. AGU, Washington DC, pp $173-185$. 
Biogeosciences Discuss., doi:10.5194/bg-2016-297, 2016

Manuscript under review for journal Biogeosciences

Published: 24 August 2016

(c) Author(s) 2016. CC-BY 3.0 License.

(c) (i)

Grasshoff K. \& Johannsen H. (1972) A new sensitive and direct method for the automatic determination of ammonia in sea water. Journal du Conseil 34(3), 516-521.

Gripp A. d. R., Marinho C. C., Sanches L. F., Petruzzella A. \& Esteves, F. d. A. (2013) The role played by aquatic macrophytes regarding $\mathrm{CO}_{2}$ balance in a tropical coastal lagoon (Cabiúnas Lagoon, Macaé, RJ). Acta Limnologica Brasiliensia 25(3), 291-301.

Gutierrez E., Ruiz E., Uribe E. \& Martinez J. (2001) Biomass and productivity of water hyacinth and their application in control programs. Biological and Integrated Control of Water Hyacinth, Eichhornia crassipes $102,109-199$.

Harpenslager S., Lamers L., van der Heide T., Roelofs J. \& Smolders A. (2016) Harnessing facilitation: Why successful re-introduction of Stratiotes aloides requires high densities under high nitrogen loading. Biological Conservation. 195, 17-23.

Henriksen A. (1965) An automatic method for determining low-level concentrations of phosphates in fresh and saline waters. Analyst 90(1066), 29-34.

Jianqing D., Ren W., Weidong F. \& Guoliang Z. (2001) Water hyacinth in China: Its distribution, problems and control status. Biological and integrated control of water hyacinth, Eichhornia crassipes 102.

Kamphake L., Hannah S. \& Cohen J. (1967) Automated analysis for nitrate by hydrazine reduction. Water research 1(3), 205-216.

Kosten S., Piñeiro M., de Goede E., de Klein J. \& Ettwig, K. submited. Fate of methane in free floating plant dominated systems. Water Research. 
Biogeosciences Discuss., doi:10.5194/bg-2016-297, 2016

Manuscript under review for journal Biogeosciences

Published: 24 August 2016

(c) Author(s) 2016. CC-BY 3.0 License.

Malik A. (2007) Environmental challenge vis a vis opportunity: the case of water hyacinth. Environment international 33(1), 122-138.

Mandi L. (1994) Marrakesh wastewater purification experiment using vascular aquatic plants Eichhornia crassipes and Lemna gibba. Water Science and Technology 29(4), 283-287.

5 Masifwa W., Twongo T. \& Denny, P. (2001) The impact of water hyacinth, Eichhornia crassipes (Mart) Solms on the abundance and diversity of aquatic macroinvertebrates along the shores of northern Lake Victoria, Uganda. Hydrobiologia. 452, 1/3, 79-88.

Myhre, G., Shindell, D. and Bréon F. M. (2013) Anthropogenic and Natural Radiative Forcing. Climate Change 2013: The Physical Science Basis. Contribution of Working Group I to the Fifth Assessment Report of the Intergovernmental Panel on Climate Change.

Nahlik A. \& Mitsch W. (2006) Tropical treatment wetlands dominated by free-floating macrophytes for water quality improvement in Costa Rica. Ecological Engineering. 28, 3, 246-257

Olsen S. R. (1954) Estimation of available phosphorus in soils by extraction with sodium bicarbonate.

Peixoto R. B., Marotta H., Bastviken D., \& Enrich-Prast A. (2016) Floating Aquatic Macrophytes Can Substantially Offset Open Water $\mathrm{CO}_{2}$ Emissions from Tropical Floodplain Lake Ecosystems. Ecosystems.

Pinto-Coelho R. \& Greco M. (1999) The contribution of water hyacinth (Eichhornia crassipes) and zooplankton to the internal cycling of phosphorus in the eutrophic Pampulha Reservoir, Brazil. Hydrobiologia. 411, 115127. 
Biogeosciences Discuss., doi:10.5194/bg-2016-297, 2016

Manuscript under review for journal Biogeosciences

Published: 24 August 2016

(c) Author(s) 2016. CC-BY 3.0 License.

Polprasert C. \& Khatiwada N. R. (1998) An integrated kinetic model for water hyacinth ponds used for wastewater treatment. Water Research 32(1), 179-185.

Reddy K. \& Tucker J. (1983) Productivity and nutrient uptake of water hyacinth, Eichhornia crassipes I. Effect of nitrogen source. Economic botany 37(2), 237-247.

Reddy K. \& Debusk W. (1984) Growth characteristics of aquatic macrophytes cultured in nutrient-enriched water: I. Water hyacinth, water lettuce, and pennywort. Economic Botany. 38, 2, 229-239

Reddy K. \& DeBusk W. (1991) Decomposition of water hyacinth detritus in eutrophic lake water. Hydrobiologia 211(2), 101-109.

Reddy K., Agami M. \& Tucker J. (1989) Influence of nitrogen supply rates on growth and nutrient storage by water hyacinth (Eichhornia crassipes) plants. Aquatic Botany 36(1), 33-.

Reddy K., Agami M. \& Tucker J. (1990) Influence of phosphorus on growth and nutrient storage by water hyacinth (Eichhornia crassipes (Mart.) Solms) plants. Aquatic botany 37(4), 355-365.

Thomas K., Benstead J., Davies K. \& Lloyd D. (1996) Role of wetland plants in the diurnal control of $\mathrm{CH}_{4}$ and $\mathrm{CO}_{2}$ fluxes in peat. Soil Biology and Biochemistry. 28, 1, 17-23.

Tomassen H., Smolders A. J., Limpens J., Lamers L. P. \& Roelofs, J.G. (2004) Expansion of invasive species on ombrotrophic bogs: desiccation or high N deposition? Journal of applied Ecology 41(1), 139-150.

Villamagna A. \& Murphy, B. (2010) Ecological and socio-economic impacts of invasive water hyacinth (Eichhornia crassipes): a review. Freshwater biology 55(2), 282-298. 
Biogeosciences Discuss., doi:10.5194/bg-2016-297, 2016

Manuscript under review for journal Biogeosciences

Published: 24 August 2016

(c) Author(s) 2016. CC-BY 3.0 License.

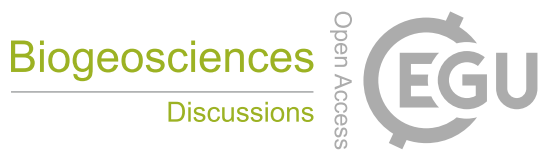

(c) (i)

Wilson J. R., Holst N. \& Rees M. (2005) Determinants and patterns of population growth in water hyacinth. Aquatic Botany 81(1), 51-67.

Xie Y., Wen M., Yu D. \& Li Y. (2004) Growth and resource allocation of water hyacinth as affected by gradually increasing nutrient concentrations. Aquatic Botany. 79, 3, 257-266.

5 Yoshida N., Iguchi H., Yurimoto H., Murakami A. \& Sakai Y. (2014) Aquatic plant surface as a niche for methanotrophs. Frontiers in Microbiology 5: 30.

Zhao F., Xi S., Yang X., Yang W., Li J., Gu B. \& He Z. (2012) Purifying eutrophic river waters with integrated floating island systems. Ecological Engineering 40, 53-60. 
Biogeosciences Discuss., doi:10.5194/bg-2016-297, 2016

Manuscript under review for journal Biogeosciences

Published: 24 August 2016

(c) Author(s) 2016. CC-BY 3.0 License.

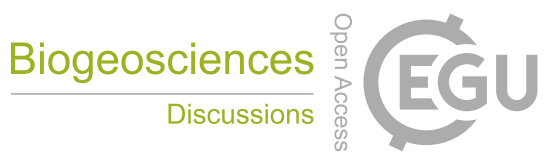

(c) (i)

Tables

Table 1 Sediment characteristics at the beginning of the experiment (mean $\pm S E M ; n=3$ ). All analyses were performed using fresh or dry sediment (see text 2.2).

\begin{tabular}{|c|c|c|}
\hline Characteristics & Unit & Sediment \\
\hline Organic matter content & $\%$ & $3.32 \pm 0.24$ \\
\hline Total-P & $\mu \mathrm{mol} \mathrm{g}{ }^{-1} \mathrm{DW}$ & $15.65 \pm 0.73$ \\
\hline Olsen-P & $\mu \mathrm{mol} \mathrm{g}{ }^{-1} \mathrm{DW}$ & $0.85 \pm 0.06$ \\
\hline Salt extractable $\mathrm{NH}_{4}{ }^{+}$ & $\mu \mathrm{mol} \mathrm{g}{ }^{-1} \mathrm{DW}$ & $0.25 \pm 0.05$ \\
\hline Salt extractable $\mathrm{NO}_{3}{ }^{-}$ & $\mu \mathrm{mol} \mathrm{g}{ }^{-1} \mathrm{DW}$ & $0.02 \pm 0.00$ \\
\hline Total-Fe & $\mu \mathrm{mol} g-1 \mathrm{DW}$ & $88.13 \pm 2.69$ \\
\hline Total-Al & $\mu \mathrm{mol} \mathrm{g}{ }^{-1} \mathrm{DW}$ & $81.49 \pm 2.20$ \\
\hline Total-Ca & $\mu \mathrm{mol} \mathrm{g}{ }^{-1} \mathrm{DW}$ & $100.43 \pm 3.83$ \\
\hline
\end{tabular}

5 
Biogeosciences Discuss., doi:10.5194/bg-2016-297, 2016

Manuscript under review for journal Biogeosciences

Published: 24 August 2016

(c) Author(s) 2016. CC-BY 3.0 License.

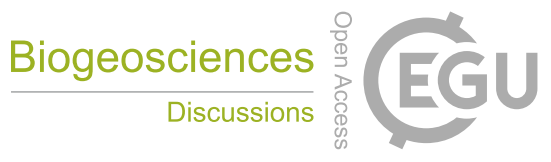

(c) (i)

Table 2 Water characteristics in surface water during the experiment. All concentrations are given in $\mu \mathrm{mol} \mathrm{L}^{-1}$. DOC concentrations were determined at the end of the experiment (mean $\pm S E M ; n=4$ ), whereas other parameters were analyzed multiple times during the experiment (overall average are given, mean $\pm S E M ; n=4$ )

\begin{tabular}{|c|c|c|c|c|c|c|}
\hline Characteristics & $\mathrm{C}$ w/o mesh & $\mathrm{C}$ with mesh & $50 \% \mathrm{nR}$ & $50 \% \mathrm{R}$ & $100 \% \mathrm{nR}$ & $100 \% \mathrm{R}$ \\
\hline DTP & $17.4 \pm 5.2^{\mathrm{a}}$ & $11.1 \pm 1.4^{\mathrm{a}}$ & $2.2 \pm 0.1^{b}$ & $7.8 \pm 4.6^{b}$ & $6.4 \pm 4.2^{b}$ & $3.7 \pm 1.3^{b}$ \\
\hline $\mathrm{NH}_{4}^{+}$ & $16.9 \pm 6.2$ & $6.2 \pm 0.6$ & $6.8 \pm 0.5$ & $60.6 \pm 54.2$ & $39.8 \pm 33.8$ & $6.2 \pm 0.6$ \\
\hline $\mathrm{NO}_{3}^{-}$ & $9.5 \pm 0.8^{\mathrm{a}}$ & $1.2 \pm 0.6^{b}$ & $1.8 \pm 1.1^{b}$ & $0.4 \pm 0.1^{b}$ & $0.6 \pm 0.2^{b}$ & $0.4 \pm 0.2^{b}$ \\
\hline DOC & $944.0 \pm 135.9$ & $890.7 \pm 331.6$ & $855.5 \pm 198.0$ & $469.3 \pm 274.3$ & $997.2 \pm 273.6$ & $629.0 \pm 145.3$ \\
\hline
\end{tabular}

Significant differences among treatments are indicated by different lower case letters.

5 
Biogeosciences Discuss., doi:10.5194/bg-2016-297, 2016

Manuscript under review for journal Biogeosciences

Published: 24 August 2016

(c) Author(s) 2016. CC-BY 3.0 License.

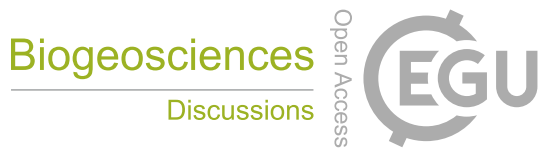

(c) (i)

Figure legends

Figure 1. Experimental design. $\mathrm{C}$ w/o mesh represents control without mesh; $\mathrm{C} w$ mesh represents control with mesh; $50 \% \mathrm{nR}$ represents low density with mesh; $50 \% \mathrm{R}$ represents low density without mesh; $100 \% \mathrm{nR}$ represents high density with mesh; $100 \% \mathrm{R}$ represents high density without mesh.

Figure 2. Mean dissolved oxygen concentrations ( \pm SEM) of the water layer at $20 \mathrm{~cm}$ depth for controls (C), low density (50\%), and high density $(100 \%)$ of water hyacinth with $(R)$ or without rooting $(n R)$ in the sediment. Different lower case letters indicate significant differences between treatments by post hoc test $(P<0.001)$.

10

Figure 3. Ratios between C and P (white), between C and N (shaded), and between N and P (dotted) in petioles (left panel) and roots (right panel) of water hyacinth for low density $(50 \%)$ and high density $(100 \%)$ with (R) or without (nR) roots in the sediment at the end and start of the experiment. All nutrient ratios are given in $\mathrm{mol} \mathrm{mol}^{-1}$. Different lower case letters indicate significant differences between treatments including the start of the experiment $(P<0.05)$. Note the $\log _{10}$ scale on the $y$-axis.

15

Figure 4. $\mathrm{CH}_{4}$ (left) and $\mathrm{CO}_{2}$ (right) fluxes ( \pm SEM) for controls (C), low density (50\%), and high density (100\%) of water hyacinth with (R) or without rooting $(\mathrm{nR})$ in the sediment. Different lower case letters and upper case letters indicate significant differences between treatments $(P<0.05)$ for diffusion and the total flux, respectively. No statistic difference was found for ebullition. Note different scales for the $y$-axis. Negative numbers refer to sequestration.

20

Figure 5. Global warming potential (GWP; mean \pm SEM) for controls (C), low density (50\%) and high density (100\%) water hyacinth coverage with or without rooting in the sediment. Different lower case letters indicate significant differences between treatments $(P<0.001)$. 
Biogeosciences Discuss., doi:10.5194/bg-2016-297, 2016

Manuscript under review for journal Biogeosciences

Published: 24 August 2016

(c) Author(s) 2016. CC-BY 3.0 License.

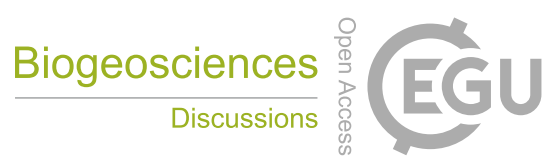

\section{(c) (i)}

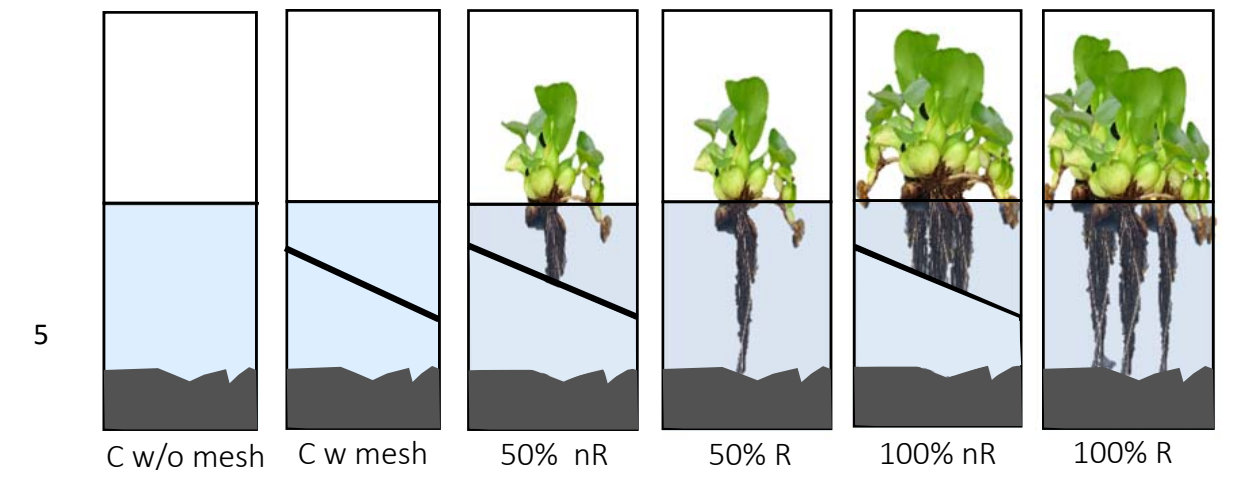

Fig 1 
Biogeosciences Discuss., doi:10.5194/bg-2016-297, 2016

Manuscript under review for journal Biogeosciences

Published: 24 August 2016

(c) Author(s) 2016. CC-BY 3.0 License.

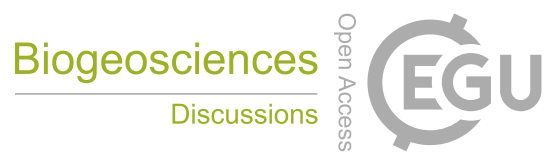

(c) $\underset{\mathrm{BY}}{\mathrm{B}}$

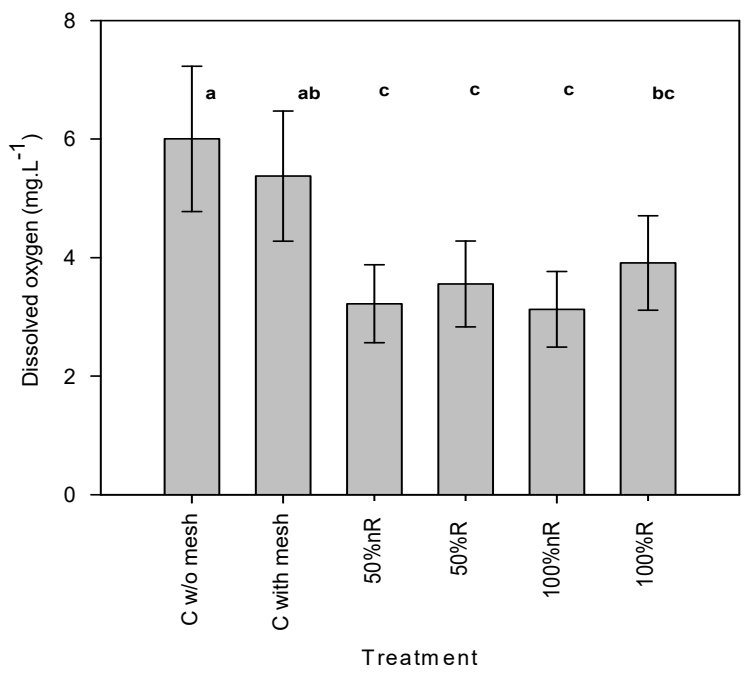

Fig 2 
Biogeosciences Discuss., doi:10.5194/bg-2016-297, 2016

Manuscript under review for journal Biogeosciences

Published: 24 August 2016

(c) Author(s) 2016. CC-BY 3.0 License.

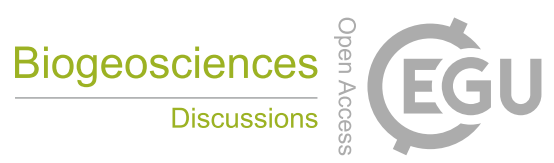

\section{(c) (i)}

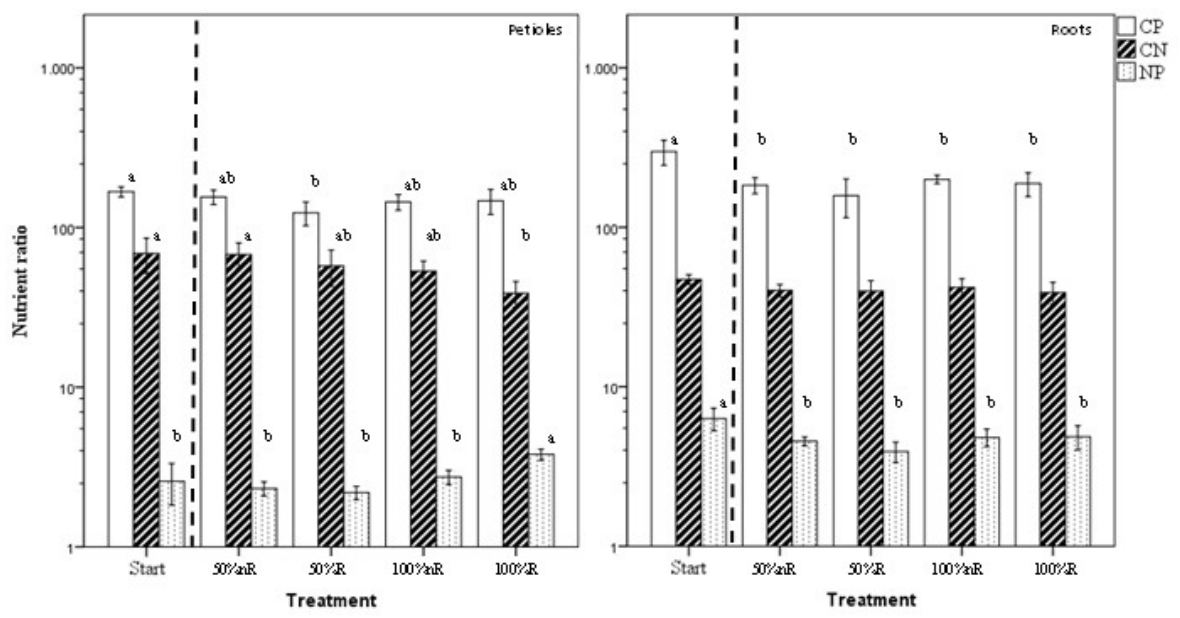

Fig 3 
Biogeosciences Discuss., doi:10.5194/bg-2016-297, 2016

Manuscript under review for journal Biogeosciences

Published: 24 August 2016

(c) Author(s) 2016. CC-BY 3.0 License.

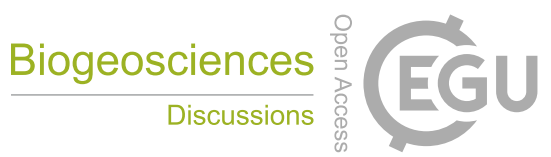

(c) (i)
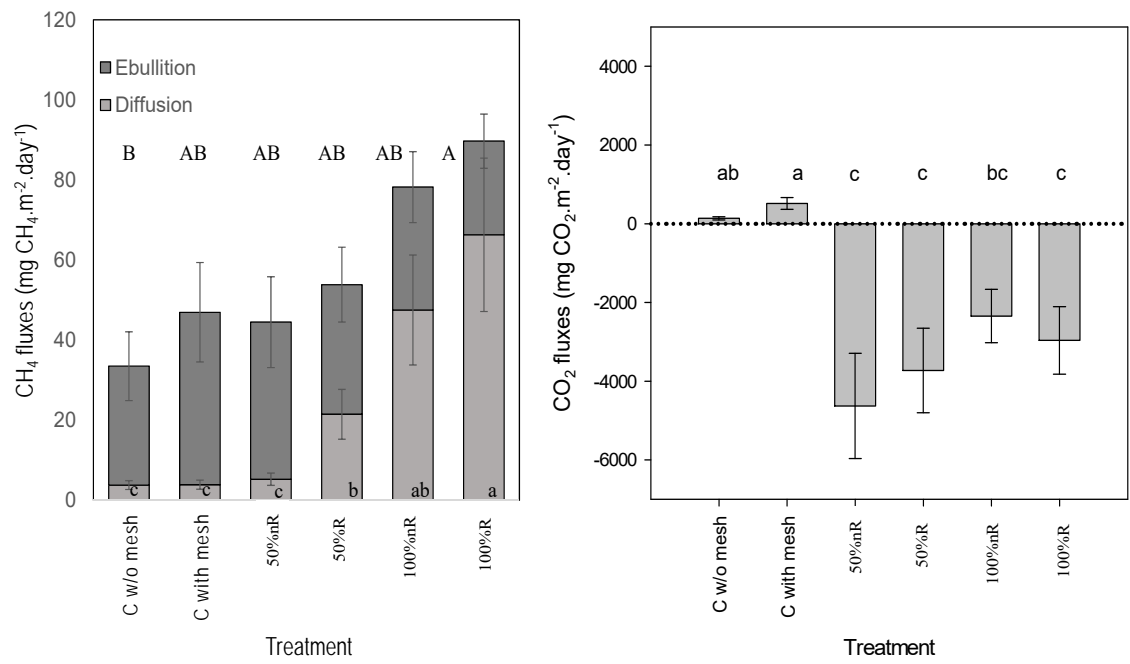

Fig 4 
Biogeosciences Discuss., doi:10.5194/bg-2016-297, 2016

Manuscript under review for journal Biogeosciences

Published: 24 August 2016

(c) Author(s) 2016. CC-BY 3.0 License.

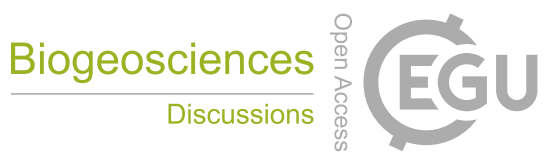

(c) (i)

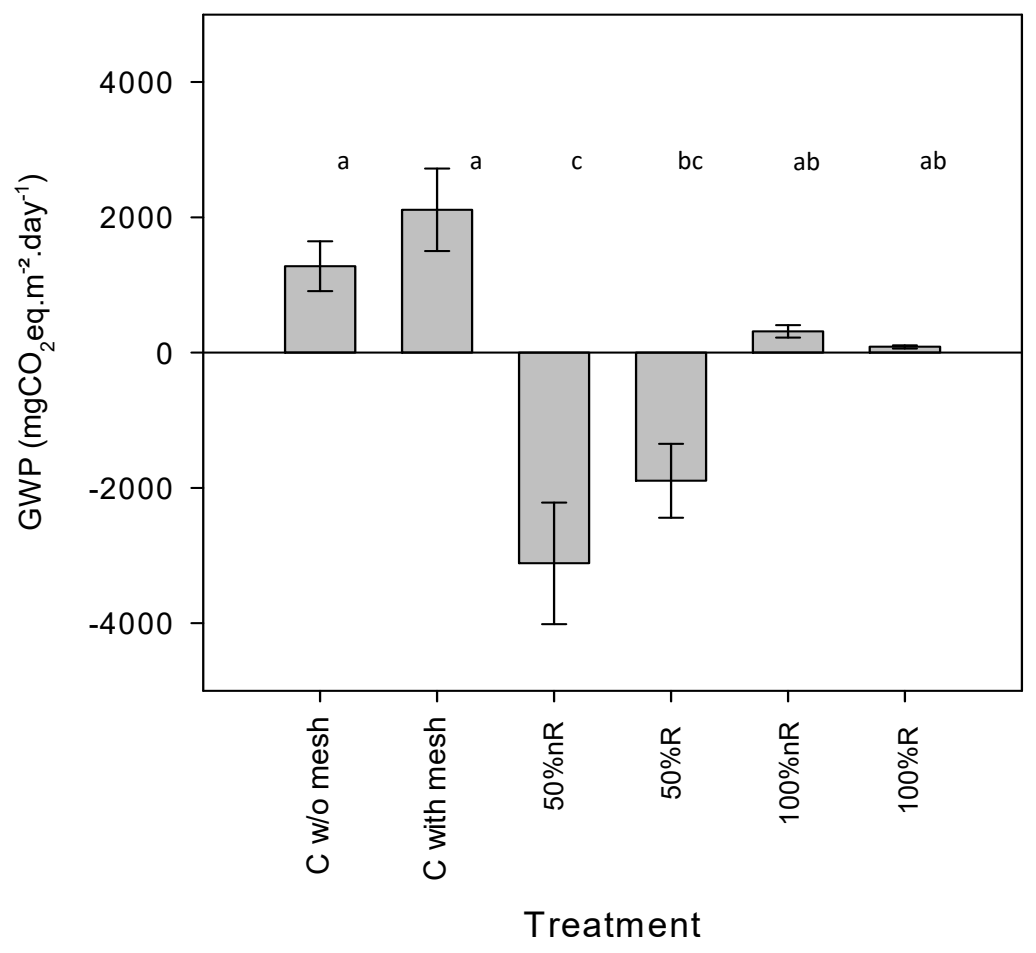

Fig 5

5 